\title{
How University Incubators may be Overprotective and Hindering the Success of the Young Firm: Findings from a Preliminary Study
}

\author{
Paul Trott \\ Professor in the Department of Technology, Strategy and Entrepreneurship at TU Delft, The Netherlands \\ Victor E. Scholten \\ Assistant professor in the Department of Technology, Strategy and Entrepreneurship at TU Delft, The Netherlands \\ Dap Hartmann \\ Assistant professor in the Department of Technology, Strategy and Entrepreneurship at TU Delft, The Netherlands
}

\begin{abstract}
This paper investigates to what extent university spin-offs benefit from their parent organization. Drawing from the resource based view and social capital theory we identify the support factors that may turn to interference with the spinoffs business goals. This study has a case study approach and data is collected among high-tech university spin-offs in the Netherlands. Preliminary findings provide insight in the extent to which support is valuable and when it can hamper the progress of the spin-off creation. Understanding the dynamics of the support can help improve the spin-off incubation programs.
\end{abstract}

Keywords: High-tech Entrepreneurship, Incubator, Spin-off Support, University Spin-offs

\section{INTRODUCTION}

$\mathrm{U}$ niversity spin-offs (USO) are typically founded by one or more scientists who have participated in academic research programmes that resulted in a scientific finding and that finding shaped the basis for their spin-off [1]. To successfully exploit the scientific finding, it is important for scientists to understand the opportunities in the market. Scientists bring to the spin-off their scientific experience and expert skills. Experience and skills are important for translating the scientific finding into a feasible business proposition. Nevertheless, spin-offs start with some major disadvantages related to their newness and smallness. Spin-offs have a strong technological orientation that may imbalance their entrepreneurial orientation. Consequently, a strong focus on transferring the scientific finding to a commercial goal is needed. As the focus shifts to market and start-up activities, spin-off entrepreneurs find themselves increasingly in new roles. The liability of "newness" is even more relevant when the knowledge to be transferred is new to the market. Besides the problems related to newness, spin-offs also experience liabilities of smallness due to a lack of resources. Spin-offs are constrained by their relatively small financial base, and lack of business experience, track records and assets. Support activities can help spin-offs to overcome their liabilities of newness and smallness.

These supportive activities can be found in the universities, from which the spin-off emerged, or in the external network in which the spin-off operates. The university can provide the spin-off with specific technological expertise or equipment $[2$, $3,4]$. Network contacts in the business environment, for instance, can help identify and evaluate a business idea and provide access to resources that are necessary during the startup process.

Empirical studies, however, have identified that while lots of spin-offs are founded, only a very small proportion grow and succeed [5]. Research by [6] on UK university spin-outs reveals that while universities are increasingly keen to create spin-out companies, far too few of these become successful businesses. The research reveals that universities seem to be focused on creating businesses rather than on creating wealth or successful start-ups. The poor performance of UK university knowledge transfer activities including USOs was highlighted by last year's Lambert Report on universitybusiness collaboration. Recent UK Government policy has encouraged universities to commercialise their intellectual property by launching entrepreneurial spin-outs. But, according to Professor Wright [6]:

"there is a distinction between the creation of spinouts per se and the creation of spin-outs that create significant wealth. Few spin-outs in the UK, for example, have been sold or floated on a stock market and, while venture capitalists expect 10-15 per cent of the new businesses they back to generate wealth, the proportion of successful USOs is currently much lower."

Similarly, Stanford University is often cited as the birthplace of famous university start-up firms such as HP, Yahoo, 
Google, Sun, and Cisco, among others. It is little wonder then that Governments around the world are encouraging their universities to engage in university spin-outs. But are these examples genuinely university spin outs? The high profile business successes of Yahoo and Google, which are sometimes used to support the notion of university spinouts, are not university spin-outs from academic research programmes. While both Yahoo and Google were founded by Stanford University students, Stanford did not claim intellectual property in the Yahoo technology because this was developed in the students' own time. In the Google case Stanford was able to generate income from ownership of the intellectual property, but most of their income comes from their $\mathrm{VC}$ investment made through local $\mathrm{VC}$ firms rather than from the licence.

Given the above discussions in this paper we examine the role of the university support and illustrate how there may be times when the university is inadvertently over protective of its young firm and thereby contributing to the problem of poor performance of university spin-outs.

\section{SUPPORTIVE UNIVERSITY INFRASTRUCTURES}

The uniqueness of a spin-off firm is that it has emerged from another organisation; we refer to as the parent organisation. University spin-offs are based on a scientific finding that resulted from a research programme. The transfer of the finding from parent to spin-off often involves that parent organisations take an equity position in the spin-offs. Hence, spin-offs have an inherent relationship with their parent organisation. Because of this long-standing relationship the parent organisation can be considered as being a strong tie. As a strong tie, the parent organisation can provide benefits in several ways and help its spin-off to achieve early growth. To conceptualise the benefits from the relationship with the parent organisation, we draw from both the social-capital and resource-based theory and take insight from studies in business incubation, and small-large firm alliances.

The parent organisation can be supportive through the transfer of explicit resources and implicit routines and legitimacy to the spin-off. Based on the resource-based view, we can conceptualise parent support into tangible and intangible assets [7]. Tangible support refers to all assets that can be physically observed, such as the provision of intellectual property rights, finance, accommodation, and other complementary resources for the start-up. Not many new spinoffs have a strong financial position and paying the market price for resources is often too expensive. Intangible support is more oriented to the provision of expertise and coaching, such as guidance and advice by the parent organisation. The university can provide entrepreneurs with these resources. Access to them is important to the early growth of the new venture. In addition, the parent can relieve the spin-off of administrative and legal tasks and help it in focusing on its major activities [4]. Furthermore, the parent can assist the spin-off in negotiations when setting up business contracts, and their technological expertise can help spin-offs to translate the research findings into commercial products $[8,9]$. In summary, the close relationship between a spin-off and its parent organisation may provide opportunities for the spin-off in terms of cost reductions, e.g. access to laboratory and expensive equipment $[10,11]$.

Using the social-capital theory, the parent organisation can provide access to certain contacts. Literature on alliances found that the partner can directly provide information and knowledge $[12,13]$ that can improve the firm's learning curve [14]. The source of entrepreneurial opportunities depends, in part, on the distribution of information in society [15]. When people interact, they are exposed to new information that can inhibit potential opportunities [16]. Consequently, the university can have through its extensive academic network help the entrepreneur in the identification process of entrepreneurial opportunities. Furthermore, a strong relationship with the parent organisation makes it easier to attract finance from either the parent organisation or others such as informal or "angel" investors [17]. New spin-offs lack a track record of customers, which makes it difficult for potential business partners to assess a new firm's credibility [18]. This liability of newness [19] is nourished by uncertainty regarding the quality of the new firm's products or services and its organisational stability that consequently results in a lack of social approval. Again, alliance literature postulates that partnerships with prominent organisations provide access to external legitimacy and status [20]. In a similar way, the university can increase the perceptions of credibility and the viability of their entrepreneurial spin-off firms.

Combining the two views can improve our knowledge of the factors that favour or hinder the success of young university spin-offs. Compared to incumbents, technological start-ups are less resource-rich firms that generally seek technical, managerial and financial resources through alliances with established market firms [21]. Consequently, the common consensus is that if spin-offs receive support from their parent organisation, they can enjoy a competitive advantage. This support, however, does not sit comfortably with the equally clear evidence from [6] which shows limited success. Yet, little empirical research is conducted that analyses to what extent specific support activities are beneficial to university spin-offs. We suggest that the success of university spin-offs follows an inverted U-shape with the extent of support activities as provided by their parent organisation. The university incubator may provide the spin-off with accommodation but at the same time it removes start-up firms from the harsh commercial environment where economic rationality and price based decision making dominates. Also, staying at the incubator may influence the spin-offs orientation. Their technology orientation focus can be too early on a product category or a market segment which precludes the possibility of development for other market 
opportunities. As a result of this product myopia, university start-ups target for inappropriate customers and miss the market opportunities elsewhere. Similarly, remaining close to the university offers easy maintenance of past networks to academic colleagues and friends. Talks with ex-colleagues are most likely to involve research publications and the improvement of core technologies, which may achieve quality levels beyond commercial demand. These relationships with existing academic contacts can hinder the development of new networks that start-up firms need to build amongst customers, suppliers and competitors. Moreover, the detrimental effect of the parent support and the incubator as a buffer to the rugged landscape of the external market may eventually affect the spin-off. The university incubator provides a cushion against the commercial reality of the competitive market place. This can cause severe problems for the firm when it leaves the incubator. This raises the question of whether the university parent may also be a hindrance? These arguments lead to the following propositions:

\section{Proposition 1: Remoteness}

The university incubator removes start-up firms from the harsh commercial environment where economic rationality and price based decision making dominates.

\section{Proposition 2. Product Myopia}

University start-up firms, with their technology orientation focus too early on a product category or a market segment which precludes the possibility of development for other market opportunities.

\section{Proposition 3. University networks}

The university incubator offers easy maintenance of past networks to academic colleagues and friends. This hinders the development of new networks that these start-up firms need to be building amongst customers, suppliers and competitors.

\section{Proposition 4. Cushion effects}

The university incubator provides a cushion against the commercial reality of the competitive market place. This can cause severe problems for the firm when it leaves the incubator.

\section{FIELD STUDY}

The data for this study is collected from case studies at the Technical University of Delft. The TU Delft is located in the Netherlands between the cities of Rotterdam and The Hague. It is the largest of the three technical universities in The Netherlands. Since 1988 the university has offered a programme of support for university spin-out companies. Since this time the level of support has varied, but it has included interest free loans, accommodation in a university building, support from academic faculty and education courses on commercial skills: including writing a business plan and intellectual property protection. Following on the success of earlier efforts, TU Delft established in 2005 an incubator based on the campus and offering additional support for technology intensive university start-up firms. It is these so called Technostarters from the university that can convert scientific findings into new products and services. Indeed, this is the economic ambition, that these fast growing firms will be the engine of economic growth in the future.

In addition to the 2005 incubator TU Delft has, in association with the City of Delft, established YES!Delft (Young Entrepreneurs Society Delft), which consists of a Business Club. In the Business Club, young engineers and students (recent graduates and undergraduates) can exchange experiences and ideas on the business community while building networks. The incubator offers technostarters support to establish a successful business. The YES!Delft Incubator is aimed at technostarters that want to develop highly technological and knowledge intensive innovations and market these in four years or less. The Incubator supports these young entrepreneurs throughout the start-up period of their business and offers them access to the knowledge, advice and facilities of TU Delft. To be granted access to the Incubator, the technostarters have to meet a number of criteria. Among other things, the feasibility of their business plans is judged. Since 1998 TU Delft has helped establish over 100 university startup firms. A few have grown into very successful businesses such as Senz umbrellas Ltd. and SunShower Ltd. But many remain small sometimes through choice but often sales and customers are hard to generate. It is from this population of university start-up firms that our field study is based. Face to face semi-structured interviews based on our four propositions have begun with the founders and entrepreneurs of a sample of these university spin-outs. Our early preliminary findings from this on-going study reveal that in addition to delivering benefits to the young technostarters incubators can in certain situations be a hindrance. This is explained further in the next section.

\section{FINDINGS}

Table 1 captures and summarises our preliminary findings. Regarding the resources, sponsorship by the parent organization clearly reduces the cost function. Respondents indicated that assets like accommodation, finance and other type of equipment were available at either low cost or at low interest rates. Moreover, the availability of these resources initially speeded up the founding process. Most resources were available at the incubator which made it easier for the spin-off to get started. However, later in the process of venture creation the accommodation did not exactly meet the criteria of the spin-off. As one spin-off entrepreneur indicated: "the spaces are like 'one size fits all', but we needed not all space whereas our neighboring tenant was claiming he could not improve the space to his wishes." Another spin-off entrepreneurs explained 
that being in the incubator was positive for the discussions with other tenants but "When I received potential customers at they often asked me about the status of the company. How long had the company been running and had we had other customers before? Other customers were interested in whether the company was operating autonomously from the knowledge institution. But there were other problems not only with customers. Other scientists would 'accidentally' walk in and look at the things we were doing and plagued our work in the laboratory. It was not only the privacy of our business we wanted to ensure. The things they touched and the questions they raised annoyed us too. At a certain point I took the door handle off." The remarks suggest that the accommodation at the incubator did raise some questions regarding the maturity of the spin-off.

Regarding the intangible resources, for some spin-offs the intellectual property rights (IPR) were essential to get started. As one entrepreneur explained: "without the IPR we could not attract investors". But at the same time the entrepreneur told us that the transfer of IPR involved extensive discussions over license agreements, the division of revenue generated and the appropriation of knowledge generated. In addition, one other spin-off entrepreneur informed us that the IPR was actually not necessary for the product-market proposition they had: "when we discussed our ideas with potential customers, they pointed out that they wanted a reliable product that does not divert too much from existing ones. Although we could do more, we had to apply less sophisticated technology to make it less expensive and get it accepted sooner by the market."

The spin-off entrepreneurs were very pleased with the networking activities and the seminars for support and coaching that the incubator organized. But these networks were not always comfortable for new opportunities as one entrepreneur comments "At many network events we came across old colleagues or other scientists, which did not help us in building relationships with suppliers and customers. We actually had to be aware that we were not sucked back into the old task environment."

The findings clearly suggest that parent support is beneficial but to a certain extent. Sponsorship reduces the cost function but, from a resource-based point of view, the support does provide the spin-off a competitive advantage if the resources are valuable, rare, imperfectly imitable and non-substitutable [22]. Although IPR often provides these competitive advantages, it does not necessarily address the value in the eyes of the customers. Also sponsorship by the parent sometimes involves extensive discussions over appropriation of value generated and bureaucratic procedures which lead to ill-conceived thinking which hampers the entrepreneurial mind-set. Also from a social-capital point of view, the spin-off can be a linking pin between the academic and business networks. As a linking pin they can gain a competitive advantage from brokering the knowledge between the business and academic network, as suggested by [23]. But as the cases made clear, there is a tendency to imbalance the network into the direction of academic networks. This may lower the likelihood that spin-off entrepreneurs spot opportunities in the business environment or develop new relationships that are driven by commercial trade-offs. As they remain close to the established academic network, they will favour the trust and efficiency that close networks promote [25] but miss the performance boost from bridging structural holes which are crucial innovative firms [26].

\section{CONCLUSION AND DiscUSSION}

These initial findings indicate that the parent organisation should not embrace the spin-off too closely as it may constrain it in its freedom and signal to others that the spin-off has not reached maturity. Parent support can benefit the spin-off if it concerns activities that help the spin-off entrepreneur to focus on transferring academic knowledge to commercial ends. A spin-off that grows independently of its parent can still make use of advice and scientific coaching by the parent and at the same time show its own ability to be a viable business. In particular there is recognition that while the university offers support the dark side of this support is also acknowledged. Clearly getting the balance right between support and interference is clearly a difficult judgement for the university incubator managers. Being aware of those areas where support is turning to interference is valuable, and helps to understand to what extent support is beneficial to the university spin-off.

The management of the spin-off activity requires up-front investment and lengthy payback periods. Universities need to consider these financial realities when framing their spin-off policy and monitoring the performance of a spin-off. A university needs to negotiate an agreement that gives it an appropriate share in any revenues, but the agreements need to be framed so that the financial interests of the university and of individual researchers do not compromise the spin-off independence. In addition, parent support based on financial capital and accommodation increases the perception among business partners that the spin-off is closely associated with the parent and may consequently lead them to question the autonomy and self-sufficiency of the spin-off. Moreover, the entanglement of resources between spin-off and universities makes the spin-off less business-oriented and if competition over these resources exists it may be frustrating. As one official at a university explained: "the competition over resources within the university may be the largest barrier for spin-offs to emerge". Furthermore, spin-offs that remain too close to the parent organisations are less likely to establish commercial opportunities and find difficulties in changing their external network to the requirements of the new task environment in the business world. 


\section{REFERENCES}

[1] F. Pirnay, "What are we talking about when we Talk about Spin-off? A Review of the Literature," 4ème Colloque International Francophone sur la PME, Metz-Nancy, October, 22-24, 1998.

[2] M.T. Hansen, H.W. Chesbrough, N. Nohria and D.N. Sull, "Networked Incubators; Hothouses of New Economy," Harvard Business Review, 2000 .

[3] O. Gassmann, and B. Becker, "Towards a Resource-Based View of Corporate Incubators International," Journal of Innovation Management, vol. 10, no. 1, 2006

[4] D.N. Allen, and R. McCluskey, "Structure, policy, services and Performance in the business incubator industry," Entrepreneurship Theory and Practice, vol. 15, no.2, pp. 61-77, 1990.

[5] R. Lambert, "Lambert review of business-university collaboration," Report by Her Majesty Stationary Office, UK, available: http://www.hm-treasury.gov.uk/consultations_and_legislation/ lambert/consult_lambert_index.cfm

[6] M. Wright, A. Lockett, B. Clarysse, and M. Binks, "University spin-out companies and venture capital," Research Policy, vol. 35, no. 4, pp. 481-501, 2006.

[7] I. Dierickx, and K. Cool, "Asset stock accumulation and sustainability of competitive advantage," Management Science, (December), 1504$1511,1993$.

[8] R.A. Jensen, J.G. Thursby, and M.C. Thursby, "Disclosure and licensing of university inventions: 'The best we can do with the $\mathrm{s} * * \mathrm{t}$ we get to work with'," International Journal of Industrial Organization, vol. 21, pp. 1271-1300, 2003.

[9] F. Murray, "The role of academic inventors in entrepreneurial firms: sharing the laboratory life," Research Policy, vol. 33, no. 4, pp. $643-$ 659, 2004.

[10] B. Kogut, "Joint ventures: theoretical and empirical perspectives," Strategic Management Journal, vol. 9, pp. 319-332, 1988.

[11] A.S. Starr, and I.C. MacMillan, "Resource co-optation via social contracting resource acquisition strategies for new resources," Strategic Management Journal, vol. 11, pp. 79-92, 1990.

[12] B. Kogut, "The network as knowledge: generative rules and the emergence of structure," Strategic Management Journal, vol. 21, pp. 405-425, 2000

[13] W. Cohen, and D. Levinthal, "Absorptive Capacity: A new perspective on learning and innovation," Administrative Science Quarterly, vol. 35 no. 1 , pp. 128-135, 1990.

[14] M. Hansen, "The search transfer problem: The role of weak ties in sharing knowledge across organization subunits," Administrative Science Quarterly, vol. 44, pp. 82-111, 1999.

[15] I. Kirzner, Perception, opportunity, and profit: studies in the theory of entrepreneurship, Chicago: University of Chicago Press, 1973.

[16] M. Granovetter, "Economic action and social structure: the problem of embeddedness," American Journal of Sociology, vol. 91, no. 3, pp. 481510, 1985.

[17] L. Steier, and R. Greenwood, "Entrepreneurship and the evolution of angel financial networks," Organization Studies, vol. 21, no. 1, pp. 163 192, 2000.

[18] M.T. Hannan, and J.H. Freeman, "Structural inertia and organizational change," American Sociological Review, vol. 49, no. 2, pp. 149-164, 1984.

[19] J. Brüderl, P. Preisendörfer, and R. Ziegler, "Survival changes of newly funded business organizations," American Sociological Review, vol. 57, pp. 227-242, 1992.

[20] T.E. Stuart, H. Ha, and R. Hybels, "Interorganizational endorsement and the performance of entrepreneurial ventures," Administrative Science Quarterly, vol. 44, pp. 315-349, 1999.

[21] M.A. Hitt, M.T. Dacin, E. Levitas, J.-L. Arregle, and A. Borza, "Partner selection in emerging and developed market contexts: resource-based and organizational learning perspectives," Academy of Management Journal, vol. 43, no. 3, pp. 449-467, 2000.

[22] J.B. Barney, "Firm resources and competitive advantage," Journal of Management, vol. 171, pp. 99-120, 1991.

[23] R.S. Burt, "Structural holes and good ideas," American Journal of Sociology, vol. 110, no. 2, pp. 349-399, 2004.

[24] J.S. Coleman, "Foundations of social theories," Cambridge, MA: Harvard University Press, 1990.
[25] A. Zaheer, and G.G. Bell, "Benefiting from network position: Firm capabilities, structural holes and performance," Strategic Management Journal, vol. 26, pp. 809-825, 2005. 